\title{
When group representations serve social change: The speeches of Patrice Lumumba during the Congolese decolonization
}

\author{
Olivier Klein ${ }^{1,2 *}$ and Laurent Licata ${ }^{2}$ \\ 'Belgian National Fund for Scientific Research, Belgium \\ ${ }^{2}$ Université Libre de Bruxelles, Belgium
}

\begin{abstract}
This article examines how group representations can be used strategically to induce social change. The speeches delivered by Patrice Lumumba during the decolonization of the Belgian Congo were analysed using the content analysis software ALCESTE. Lumumba used radically different descriptions of Belgians and Congolese depending on the period during which the speech was delivered and on the audience he was addressing (Congolese or Belgian). When addressing Belgians, he described their countrymen as benevolent allies who could assist the development of Congo, and the Congolese as pacific and friendly. When addressing Congolese audiences, Belgians were described as oppressors, and Congolese as victims. In addition he emphasized the unity of the country more at the end of the decolonization process than at its onset. Considering that his nationalist and pan-African aims remained stable, we suggest that this variability stems from the different actions expected from his audiences, as a function of their group membership and the political context. We argue that this performative dimension cannot be captured if group representations, including stereotypes, are only viewed in cognitive terms. In addition, we show that they should be studied not only as justifications for the existing social order but also as instruments of social change.
\end{abstract}

The relationship between representations of social groups and intergroup relations have mainly been studied in one of two ways. A long tradition of research has examined the impact of the evolution of intergroup relations on the content of these representations (for recent examples, see Alexander, Brewer, \& Hermann, 1999; Bar-Tal, 1997; Bar-Tal \& Labin, 2001; Licata, 2001). Scholars (Jost \& Banaji, 1994; Sidanius \& Pratto, 1999; Staerklé, 2003) have also examined the impact of group representations ${ }^{1}$ on social inertia by examining their role in the legitimization of the social order. Following recent work on the use of group representations by political

\footnotetext{
*Requests for reprints should be addressed to Dr Olivier Klein, Service de Psychologie Sociale CP I22, Université Libre de Bruxelles, 50 av. F. Roosevelt, 1050 Bruxelles, Belgium (e-mail: oklein@ulb.ac.be).

'The term 'group representations' will be used to refer both to representations of entire groups, i.e. of qualities attributed to the group as a whole (such as, e.g. group images [Alexander, Brewer, \& Hermann, 1999], category constructions [Reicher \& Hopkins, 1996a, 1996b, 200 la, 200 lb] and group beliefs [Bar-Tal, 1990]) and to representations of individual group members (namely stereotypes). Although those representations are cognitively differentiated, this distinction is not crucial for the argument presented here as it concerns their rhetorical use rather than their perceptual basis.
} 
speakers (see Reicher \& Hopkins, 2001b, for a review), we will move beyond these perspectives by concentrating on the role such representations can play in the transformation of social systems. We shall argue that they can be used for mobilizing audiences into supporting political projects of social change. The validity of this perspective will be examined through an analysis of the speeches delivered by the Congolese leader Patrice Lumumba during a period of rapid social transformation.

Recent research on the representations of social groups has predominantly concentrated on the individual cognitive processes involved in the formation and use of these representations (see Fiske, 1998, for a review). In contrast to this perspective, selfcategorization theory (SCT: Oakes, Haslam, \& Turner, 1994; Turner, Hogg, Oakes, Reicher, \& Wetherell, 1987) argues that adhesion to mental representations of a social group is a flexible process depending on the content of the social identity that is currently salient. Salience of a social identity is influenced by the frame of reference; i.e., the social categories that are relevant in the social context and the relations between these social categories. By viewing group representations as determined by the frame of reference (for evidence, see: Bar-Tal \& Labin, 2001; Haslam \& Turner, 1992, 1995; Haslam, Turner, Oakes, McGarty, \& Hayes, 1992; Hopkins \& Moore, 2001; Hopkins \& Rae, 2001; Hopkins, Regan, \& Abell, 1997; Licata, 2001; Rutland \& Cinnirella, 2000), SCT suggests that the social change of intergroup relations would stand as a major determinant of the content of group representations. According to this theory, variability in these representations results from changes in the context of intergroup relations by affecting the cognitive salience of social categories.

Work informed by this tradition of research has demonstrated that the social context affected the content of group representations. However, the reverse could be equally true. Indeed, at least three recently developed theoretical frameworks, social dominance theory (SDT: Pratto, Sidanius, Stallworth, \& Malle, 1994; Sidanius \& Pratto, 1999); system-justification theory (SJT: Jost, 1995; Jost \& Banaji, 1994; Jost, Burgess, \& Mosso, 2001) and subjective essentialism theory (SET: Yzerbyt, Corneille, \& Estrada, 2001; Yzerbyt \& Rogier, 2001; Yzerbyt, Schadron, \& Rocher, 1997), argue that stereotypes and representations of social groups play a role in social change by legitimizing the social order. For example, some social stereotypes may fulfil such a function by explaining the existing social structure through characterizations of group members as possessing different personality traits. They are not held exclusively by the dominant group: disadvantaged groups adhere to them as well (Jost \& Banaji, 1994; Sidanius \& Pratto, 1999), contributing to the reproduction of the very ideology that perpetuates their misfortune. According to this perspective, stereotypes hinder collective action on the part of the disadvantaged and contribute to the persistence of the status quo.

By considering group representations as consequences of social change or as impediments to it, these theories obscure the fact that group representations can also contribute to social change. A theoretical perspective that explicitly acknowledges this function is social representations theory (SRT: Farr \& Moscovici, 1984; Moscovici, 1961). Social representations are viewed as collectively elaborated understandings of the social world. These social representations orient individual as well as collective action and ultimately condition the occurrence of social change. More specifically, social representations of the in-group and of its relation to the social context are particularly crucial, as they contribute to defining the group's social identity (Augoustinos, 2001; Breakwell, 1993, 2001; Vala, 1998). As Markovà (1996) emphasized, social representations have a double-sided nature; they constitute the context in which individuals and groups communicate and act at the same time as they 
are themselves constituted by these communications and actions. Hence, the concept is inherently linked to social transformation. Contrary to Durkheim's collective representations (Durkheim, 1898), which were seen as stable social facts independent of individual actions, social representations are construed through active communication in the 'public sphere' (Habermas, 1987; Jovchelovitch, 2001) embedded in contemporary societies. It is through communication and interaction between social units in the context of this sphere that these representations are collectively negotiated.

Thus, social representations are inherently argumentative (Wagner, 1995); their nature and content emerges through a dynamic network of social influence. By using the 'agora' to influence majorities into adopting different understandings of the nature of the social world, minorities can orient their practice and action, and expect to induce social change (Moscovici, 1976; Mugny, 1982; Mugny, Quiamzade, \& Tafani, 2001). Hence, to a large extent, it is through this argumentative function that social representations can contribute to social change.

Yet, this rhetorical dimension has been somewhat neglected by the social representation tradition (Augoustinos, 2001) at least at the empirical level. By contrast, it is the focus of a discursive approach to social psychology. Like SRT, this perspective (Billig, 1985, 1987, 1995; Potter \& Wetherell, 1987; Wetherell \& Potter, 1992) rejects purely perceptual accounts of social categorizations and stereotypes. Group representations and social categories are seen as 'actively constructed in discourse for rhetorical ends' (Wetherell \& Potter, 1992). Understanding the nature and content of categories therefore depends on envisaging the argumentative context in which these representations are embedded. Thus, depending on the point being made by the speaker, different representations may be used. Conversely, the same representation can be used for achieving very different purposes. In turn, this argumentative context is viewed as being determined by the audience's position in the social context. Different audiences may be thought to endorse different viewpoints or opinions. Speakers may therefore adjust their discourse, and hence the content of their representations, to these audiences.

Given the central role played by the 'public sphere' in the elaboration of social representations, understanding how group representations can contribute to social change requires us to examine how they are employed and used by public speakers. In a programme of research influenced both by SCT and by discourse analysis, Reicher and Hopkins (1996a, 1996b; Reicher \& Hopkins, 2001a, 2001b; Reicher, Hopkins, \& Condor, 1997) have attempted to understand precisely how 'category constructions' could be used by political leaders to induce social change. They assume that, in a similar way to the acceptance of the status quo, collective action leading to social change is predicated upon particular definitions of the identity of the in-group (for evidence, see Reicher, 1984, 1996a). Hence, political speakers who wish to influence mass mobilization will define self-categories in ways that entail policies and actions that match the speaker's political agenda (Reicher \& Hopkins, 2001b).

Like SCT, this strategic perspective also acknowledges the impact of the frame of reference on the cognitive salience of social categories. However, in line with social psychological approaches to discourse analysis, it further suggests that, within the framework of a single social identity, different group representations can be expressed as a function of the specific actions expected from the audience. In this regard, engaging an audience into performing actions consistent with a political objective may demand different representations depending on the identity of the audience, and, 
more specifically, depending on the actions expected from this audience. Hence, a communicator may attribute different qualities to a group as a function of the audience (see Klein, 2000; Klein \& Azzi, 2001; Klein, Azzi, Brito, \& Berckmans, 2000, for empirical evidence) and this can be true in the context of a single political project. For example, Klein et al. (2000) have conducted an experiment with Belgian participants, who were either very favourable to the persistence of the Belgian state (high unitarists) or neutral with respect to this issue (low unitarists). High unitarists described their country less as a single 'entitative' nation when they addressed fellow French speakers (perceived as unitarists) than when they addressed Dutch speakers (perceived as separatists). This, however, was mainly true when the possible separation of Belgium between French and Dutch speakers was made salient. Low unitarists were not affected by either of these manipulations. Faced with a threat, high unitarists may have been motivated to convince their separatist audience that Belgium indeed formed a nation, thereby mobilizing them into supporting the continued unity of the State.

If we follow this perspective (see also Chryssochoou \& Volpato, 2002; Haslam, Turner, Oakes, McGarty, \& Reynolds, 1998), group representations should not only be viewed as serving to justify existing states of affairs, but they should also be seen as justifying 'utopias', i.e. political projects aimed at disrupting the existing social order (Mannheim, 1929/1972; Ricoeur, 1986). While the former aspect can, at least partially, be captured by considering group representations in perceptual terms, addressing the latter dimension demands viewing them as rhetorical tools.

In spite of the emphasis placed on a rhetorical view of category constructions (Reicher \& Hopkins, 1996a, 1996b, 2001a, 2001b; Reicher et al., 1997), the impact of different audiences on the use of these constructions by political speakers has not been systematically investigated. Indeed, Reicher and Hopkins' research has focused on the argumentative role played by these representations in relation to the mobilization of in-group members only. To extend this perspective, we suggest that group representations can be used to mobilize both in-group and out-group members. To the extent that the collaboration of an out-group is needed for the implementation of a political project (Reicher, 1996b), persuasive efforts should be directed towards members of the out-group as well.

Similarly, existing research has primarily focused on the characterization of selfcategories (see Reicher \& Hopkins, 1996a, 1996b, Reicher et al., 1997). However, the strategic perspective developed above applies to representations of both the in-group and the out-group: insofar as identities are contextual and are defined in relation to other identities (Turner et al., 1987), providing a particular representation of the in-group necessarily entails providing a definition of the out-group.

To sum up, as different actions are expected from in-group and out-group members, the representations of both the in-group and relevant out-groups mobilized by a political speaker when addressing different audiences can be analysed in terms of their overarching rhetorical function, i.e. serving a single political project. Apparent contradictions between the content of different group representations may then be understood in light of their strategic function in relation to specific audiences.

At an empirical level, this analysis allows us to put forward three assumptions regarding the use of group representations by political speakers:

(1) The variability in group representations expressed by a communicator adhering to a single political project can be partially explained by the nature of the reactions expected from specific audiences. 
(2) The content of these representations is tailored to produce reactions consonant with the realization of the speaker's political project.

(3) This variability cannot be fully explained in terms of changes in the texture of intergroup relations (the 'frame of reference') as they affect the cognitive salience of social categories, i.e. it is not only a cognitive consequence of past social change (as can be argued on the basis of the SJT, SDT and of a cognitive interpretation of SCT).

To test the validity of this perspective, we shall confront it with a historical instance of social change. Between 1958 and 1960, the Belgian Congo experienced radical political change. We carried out an analysis of the speeches delivered during this period by the Congolese political leader Patrice Lumumba, who played a central role in the mobilization process that made this change possible (De Vos, 1961; Gerard-Libois \& Heinen, 1989; Ngoma-Binda, 1997; Nyunda, 1997; Willame, 1994). The use of such material deprives us of some of the advantages of more traditional methods, such as experimental control and an opportunity to isolate the impact of different independent variables unambiguously. However, it also confers several important advantages: first, it allows us to integrate a historical dimension into our analysis. This dimension is obviously crucial if we want to assess the use of group representations in the transformation of actual social systems, and especially to demonstrate the validity of point 3 above. Second, the availability of a large sample of speeches addressed to different audiences enables us to examine how the audience's group membership affected the content of Lumumba's discourse and, in so doing, to examine assumption 1 above. The use of this material also allows us to extend earlier work by Reicher and Hopkins (Reicher \& Hopkins, 1996a, 1996b, 2001a, 2001b; Reicher et al., 1997) by taking time and the audience's group membership simultaneously into account. Finally, it enables us to examine whether the framework that has already been tested in the laboratory (Klein, 2000; Klein \& Azzi, 2001; Klein et al., 2000) withstands a confrontation with a naturally occurring chain of events, in a sociocultural context far remote from that used in those studies.

\section{Genesis of Lumumba's political project}

In view of the central role that political projects play in the theoretical perspective presented here, it is crucial to describe the genesis of Lumumba's political agenda. Belgium received the colony from its previous 'owner', King Leopold II, in 1908, and sustained an oppressive colonial system based on a paternalistic relationship with the local population (Hodgkin, 1956; Martelli, 1962; Stengers, 1989; see also Hochschild, 1998; Marchal, 1999, 2000, 2001). In the mid-1950s, this colonial order was still extremely robust. According to Stengers (1989), in 1956, it was 'so stable, assured, rock-solid that political perils were viewed as very unlikely . . . The real preoccupation of the Whites was the multiple faults of character attributed to the Blacks, which they complained about. . . Being pilferers by nature, they would become thieves if they were educated in the European way' (p. 200, our translation). Among the local population, the superiority of the 'White Man' seemed almost consensual as well (Stengers, 1989).

Up to this period, the state of the Belgian Congo is consonant with Tajfel's (1981a) description of a quiescent social system in which cognitive alternatives are absent. In this context, stereotypes of Blacks seem to have fulfilled a function of 
system-justification (Jost \& Banaji, 1994). During this period, Patrice Lumumba adhered to the Belgian colonial project. He explicitly expressed his sympathy for the Belgians (De Vos, 1961), rejected independence as premature, and was favourable to the creation of a federation uniting Belgium and Congo as a continuation of the colonial endeavour (Lumumba, 1962 2 ). At that time, he was a fervent supporter of the policy of individual mobility adopted by the Belgians and he supported a social distinction between the literate Congolese and the others (Ngoma-Binda, 1997; Willame, 1994).

Lumumba's faith in the colonial system had begun to crack by 1957 (see De Vos, 1961; Klein, 2000; Willame, 1994, for detailed analyses). Most importantly, members of the local elites, including himself, realized that in spite of the many efforts required for attaining a higher status, they remained 'Blacks' in the eyes of the Belgians and were still denied social recognition. This is compatible with theories of intergroup relations (Tajfel, 1981; Tajfel \& Turner, 1986; Taylor \& McKirnan, 1984); in the absence of opportunities for individual social mobility, social change was sought. Other important factors in Lumumba's abandonment of the colonial project were his meeting with nationalist leaders from other parts of the country at the Brussels World Fair (1958) and the independence achieved by other African states.

These factors led Lumumba to develop a radically different political project. Influenced by President Nkrumah of Ghana, he adhered to pan-Africanism, a political project supporting the creation of a single African independent State encompassing all of sub-Saharan Africa. He founded the Mouvement National Congolais (MNC), a political party, to help realize this project. In his view, a unified and independent Congolese state, representing all the Congolese people democratically, was a prerequisite for the implementation of this project (Willame, 1994). This insistence on a centralized Congolese state was opposed by the political projects pursued by rival nationalist leaders, who favoured a federal system (with a strong decentralization of power to the provinces) or a division of Congo. From October 1958, he kept the same general project of pan-Africanism, repeatedly stating it during the whole period (Ngoma-Binda, 1997). This consistency allows us to discard the possibility that variability in the group representations used by Lumumba throughout this period depends on changes in his general project. As chief of the MNC, Lumumba devoted considerable efforts to the rallying of the Congolese people to his nationalist project. Indeed, in 1958 and early 1959, most were still favourable to the persistence of the colonial regime, or at least not opposed to it (Martelli, 1962; Stengers, 1989).

\section{Historical context}

The period we investigate here started with the creation of the MNC (October 1958). This event, although not a direct cause, was followed by riots in Léopoldville in January 1959 at a meeting of a rival nationalist party, which resulted in the death of more than 200 Congolese. Fearing a violent conflict (like in Algeria), the King of Belgium then made a crucial declaration stating that his country would 'lead the Congo to independence', without defining the date or the form this independence would take. Although independence was still viewed as premature by all the Belgian leaders (including the King), Congolese nationalist leaders, including Lumumba, wanted to achieve it as early as possible (De Vos, 1961; Willame, 1994).

${ }^{2}$ This book was written in 1956. 
After intense pressure on the Belgian government and mobilization of an important part of the Congolese population, they set up the organization of a Round Table including representatives of both sides in January and February 1960. On the basis of this Round Table, elections were planned for May and June 1960 and independence was scheduled for 30 June.

A coalition led by Lumumba won the elections and he was appointed Prime Minister of the new government with Joseph Kasa-Vubu as President. However, Black soldiers of the armed forces rebelled against their White officers on 4 July. On 11 July, the province of Katanga (the economic centre of the country), proclaimed its separation from Congo with the military and political support of the Belgian Government, who wanted to secure its assets in the province (mainly the mining company, 'Union Minière'). A civil war ensued and other provinces revealed separatist inclinations. Lumumba requested the assistance of the United Nations. A UN peacekeeping force was sent but it remained neutral which, in effect, legitimized the secession of Katanga. He was dismissed by Kasa-Vubu on 5 September, allegedly for being unable to resolve the conflict, and was eventually murdered in January 1961, probably with the tacit support of the Belgian government and the new ruler, Colonel Joseph Desire Mobutu (Braeckman, 2002; De Witte, 1999; Wrong, 2000). This cursory overview of the political history of Congo between December 1958 and January 1961 clearly shows that intergroup relations underwent a dramatic change between these two dates; from an almost undisputed Belgian colony, Congo became an independent state and was subsequently deprived of the region providing most of its economic assets.

\section{General hypotheses}

According to the strategic perspective presented above, group representations are communicated to mobilize audiences into supporting the speaker's political position. In this view, the content of these representations should vary as a function of the reactions expected from the audience. These reactions, in turn, should depend on the group membership of the individuals in the audience and on the relative position of this group with respect to the communicator's group. In the present instance, a distinction that should be central is the opposition between Belgian and Congolese audiences, as the conflict mainly involved these two groups. Another factor that may influence this content is time. As the relations between the groups changed from the beginning of this period to its end, it is likely that the accomplishment of a specific political project should require different reactions on the part of the audience; hence, we expect that variations in the use of group representations will depend on the period at which the representation was expressed and on the audience's group membership, while all the time remaining consistent with Lumumba's nationalist project.

\section{Method}

\section{The textual corpus}

We base our analysis on the collection of speeches produced by Lumumba between December 1958 and January 1961 as transcribed from tape recordings by Van Lierde (1963/1972). This corpus $(59,724$ words) includes most of the speeches delivered during this period. It also contains transcriptions of other political material intended 
for the public, as these texts should be as relevant as the speeches to our theoretical analysis. Overall, the corpus included 17 speeches delivered directly in front of an audience or on the radio, 7 transcriptions of press conferences, 13 press releases, and 2 interviews. We did not include texts not intended for the public, such as personal letters.

\section{Analysis strategy}

We submitted the corpus to a lexical analysis computer program, ALCESTE (Reinert, 1996). In the ALCESTE method, the initial text is broken down into elementary contextual units (ECUs), which approximately match the size of a sentence (these are determined both according to the number of analysed words and according to punctuation). Only 'full words' (nouns, verbs, adjectives, adverbs) are analysed; 'tool words' (articles, pronouns, conjunctions) are excluded. These 'full words' are reduced to their root (e.g. 'democra+' will include 'democratic', 'democracy', etc). The corpus is then analysed as a function of their presence in the ECUs. The ECUs and the reduced forms are crossed to form a contingency table, which displays the distribution of the vocabulary as a function of the ECUs. From this contingency table, a square distance matrix is generated: two ECUs are close to each other if they share some analysed words. For example, the ECU 'And the old colonies that settled in America have fought to end the oppression, the greedy exploitation' is close to the ECU 'They forget that evolution does not move backwards and that universal consciousness now condemns colonial crusades and any policy of domination, or exploitation, of a man by another' because they have the analysed words 'colon+' and 'exploit+' in common, whilst the ECU 'Obviously, during the montbs to come, we are planning to publish a newspaper of the party, which will be a link between the party and its members' which does not have any analysed word in common with the previous ECUs, is very distant from them. A descending hierarchical cluster analysis is then performed on this distance table, which yields classes of ECUs that best differentiate the vocabulary. In so doing, this software assists in the interpretation of texts; it extracts classes of words that co-occur and that are best differentiated from other classes. This enables the researcher to identify the main 'lexical universes' (Reinert, 1993) that are present in the corpus. Once these lexical classes have been identified, one can examine whether they are associated with 'passive' variables - in this case, the audience's group membership and the time period (see below) - that do not participate in the computation of the classes.

Note, on the one hand, that this procedure is blind to the meaning of the words and, on the other hand, that it follows an inductive logic. It does not compare directly, for instance, texts that were addressed to African audiences and those that were addressed to Belgian audiences. Rather, it compares all the contextual units (ECU) that constitute the whole corpus, then it categorizes them according to their resemblance, and finally it looks for potential associations between each lexical class and independent variables that have been introduced in the analysis. The researchers' intervention during the textual analyses process is therefore very limited.

By extracting classes and excerpts automatically, ALCESTE eliminates part of the interpretative 'burden' necessarily present in similar work relying on discourse analysis (Reicher \& Hopkins 1996a, 1996b; Reicher et al., 1997). However, this is not to say that the argumentative value of the excerpts selected by ALCESTE is self-evident. In order to analyse these excerpts as productively as possible, we adapted the method of 
discourse analysis described by Potter and Wetherell (1987). First, we collected all the excerpts that ALCESTE reported as being associated with each lexical class. ${ }^{3} \mathrm{We}$ examined how they were related to the discursive contexts in which they were embedded. Next, we tried to examine their internal consistency and whether they were compatible with the general arguments developed in other excerpts associated with this class.

In adopting this hybrid analysis strategy (see also Licata \& Klein, 2000), we explicitly rely on a more macroscopic perspective than in other forms of discourse analysis (see, e.g., Potter \& Wetherell, 1987). This deprives us of the opportunity to report the argumentative processes underlying each speech in detail. Several scholars (Edwards \& Potter, 1992; Reicher \& Hopkins, 1996a) have criticized content analysis for involving 'gross categorizations', or for concealing the meaning of an instance in the context of the whole argument (Beardsworth, 1980). ALCESTE is less vulnerable to these biases. First, unlike other content analysis programs, it does not categorize words as a function of their meaning but as a function of their co-occurrence within lexical contexts. Hence, the context in which a word appears determines the categorization. ALCESTE currently seems to be the most appropriate tool for performing such 'contextualized' content analyses (Kronberger \& Wagner, 2000). Second, ALCESTE yields segments of speeches computed as illustrative of each class (as a function of their vocabulary). The analyst can then examine the argumentative function of these excerpts in each speech.

We analysed these speeches regardless of their direct relevance to stereotypes and group representations. Irrelevant discourse excerpts will be put aside at a later stage of the process (see below). This allowed us to further maximize objectivity by basing our analysis on a classification that was selected by the software as best reflecting the lexical organization of the whole corpus. Our analysis of group representations could then be considered in the context of this particular organization. The reverse strategy would have demanded to consider argumentation as a function of pre-selected representations, a method that would have been highly sensitive to numerous biases (such as considering only the arguments that seem clearly related to particular representations, whereas others may turn out to be much more central).

\section{Results}

ALCESTE extracted six classes of ECUs. We will examine classes 1, 2, 3 and 6, as these specifically concern group representations, our main interest here. Note that these four classes account for the majority of ECUs (72\%). ${ }^{4}$

\section{Contents of the classes}

Class I: Anti-colonialism (I $7.5 \%$ of ECUs)

In line with earlier uses of ALCESTE (see, e.g., Boudes \& Cellier, 1998), the vocabulary characterizing this class was divided into subclasses in order to facilitate the presentation (the frequency of each word is parenthesized; only words with frequencies higher than 5 are reported).

\footnotetext{
${ }^{3}$ An exhaustive list of these excerpts is available upon request (oklein@ulb.ac.be) or on the internet (http://www.ulb.ac.be/ psycho/psysoclappendix.htm).

${ }^{4}$ Information on the two other classes is available upon request or on the internet: http://www.ulb.ac.be/psycho/psysocl appendix.htm).
} 
(1) Colonial regime: colonial $^{5}$ (56), power (22), regime (32), imperialism (15), old (15), colony (11), West (8), Western (6), end (regime) (13)).

(2) Regime's actions against Congolese people: people (45), exploit (12), citizen (10), domination (9), tribal (8), injustice (8), fundamental (7), oppression (7), racism (8), discriminate (6).

(3) Restore violated values and rights: freedom (29), rights (23), free (15), liberation (13), declaration (12), human (13), liberate (11), democracy (11), fight (9), dignity (9), universal (8), persevere (8), fundamental (7), French (7), America (6), law (6).

(4) Other: simple (12), year (10), enjoy (7), consider (6), religion (7), legal (7), fatherland (7), title (6).

The first subclass concerns the colonial regime and its attributes. The second subclass refers to the actions undertaken by this regime (oppression, exploit, abuse, etc.) and the outcome of these actions (separatism, enslavement, racism, tribalism, etc.). The third subclass concerns human values and principles transgressed by the regime and that Lumumba hopes to restore in Congo (universal human rights, dignity, democracy like in France and America, etc.) as well as the actions that should be taken to reach this goal (die, fight, persevere, etc.).

As mentioned above, ALCESTE also extracts several ECUs typical of each class. Below are two examples of ECUs strongly associated with class 1:

We are simply against domination, injustices, abuse, and merely want to free ourselves from the shackles of colonialism and all its consequences. These injustices and the stupid superiority complex displayed by the colonialists are ... the source of the tragedy of Western presence in Africa. (Léopoldville, December 1958, p. 57). ${ }^{6}$

The one thing we are determined to do-and we would like others to understand us-is to root out colonialism and imperialism from Africa. We have long suffered and today we want to breathe the air of freedom. The Creator has given us this share of the earth that goes by the name of the African continent; it belongs to us and we are its only masters. (Ibadan, March 1959, p. 72).

In the excerpts selected as illustrative of class 1, Lumumba uncovers what he considers to be the inherent hypocrisy of the colonial regime. He stigmatizes its oppression of local Congolese populations and its ideology, which alienates Blacks. He also rejects the colonialist ideology as a form of 'false consciousness'. In line with his project, he describes the Belgians as greedy colonialists. On the other hand, the Congolese are described as an oppressed people who deserve to be free and independent. He legitimizes his claims to an independent Congo by comparing the situation of Congo to that of Western countries in pre-revolutionary times. He claims that just as France, Belgium and the USA, the Congolese people are entitled to freedom according to the Universal Declaration of Human Rights. Ultimately, he invokes God (see the second excerpt above) who 'gave' Africa to the Africans.

Class 2: Cooperation (35.5\% of the ECUs)

Again, we divided this class into subclasses:

(1) Relationship between Congo and other countries: Congo (130), country (107), Belgian (88), European (31), Congolese (19), cooperative (19), friendship (18),

\footnotetext{
${ }^{5}$ ALCESTE classifies words on the basis of their roots. Hence, colonial will be considered as equivalent to 'colonialism'. Numbers in parentheses represents weights (number of times each word appears within this class).

${ }^{6}$ Excerpts from speeches can be found in Van Lierde (1963/1972). The ECU proper is in italics. The rest of the excerpt is its immediate context.
} 
need (18), foreign (15), help (12), relation (12), good (12), collaboration (10), open (10), listen (7), Ghana (7), exchange (6), (open) arms (6).

(2) Evolution: go (102), independent (78), young (22), year (17), new (16), ensure (future of Congo) (16), effort (14), child (14) development (13), life (13), evolving (11), become (10), teaching (9), adapt (8), study (6).

(3) Economy and workforce: economy (41), work (39), technician (23), money (21), executives (17), settle (Belgian technicians in Congo) (17), goods (13), invest (11), company (10), capital (9), industry (8), capable (workforce) (8), financial (7), farmer (6).

(4) Other: social (16), only (14), view (14), know (12), presently (12), June (9), (to) mean (9), faith (8), desire (7), culture (7), impression (6), resolute (6), hoard (6), sufficient (6), capable (8), rural (6).

The first subclass includes words describing the cooperative relations between Congo and Belgium (as well as other Western countries) that Lumumba envisions. The second subclass evokes the development and the future of Congo. The third involves words related to the economy, finances and the workforce.

Typical ECUs for this class are:

To us, independence does not mean the expulsion of the Europeans now in the Congo; to us, independence does not mean a severing of our relations with Belgium. We are well aware that for many years now the Belgian people in the mother country have condemned the colonial regime enslaving fourteen million people. We are well aware that each time we come to Belgium, men, women and children welcome us with open arms. We are well aware that our Congolese brothers who have lived for years in Belgium have never suffered, never complained about their relations with the Belgians. (Brussels, February 1960, p. 164).

I know that after Congolese independence, we will ask many Belgians to help us in Congo and many young Congolese will seek a specialization in Belgium. (Stanleyville, October 1959, p. 200).

Excerpts associated with this second class typically describe Congo as an economically underdeveloped 'infant' State. In order to reach its full potential, the young State would need the assistance of Western powers (especially Belgium). This assistance should take the form of financial aid and skilled labour. Conversely, young Congolese should be educated in Belgium in the framework of youth exchange programmes. Ultimately, Belgium and Congo should become partners of equal status. Also, in several ECUs selected through the ALCESTE method as illustrative of this class, Lumumba contests the negative stereotypes held by Belgians about his countrymen. These stereotypes describe the Congolese as 'thieves', 'looters', and 'anti-Belgian'. He consistently repeats that the latter hold friendly intentions towards the Belgians. In support of these claims, he reports his frequent positive encounters with Belgians in Congo and in Belgium.

Class 3: Unitarianism (I I.3\% of the ECUs)

(1) Union: African (26), unity (25), national (23), Africa (21), brother (20), State (19), nation (15), whole (12), republic (12), black (11), integrity (9), united (8), countrymen (6), continent (9), territory (8), Bakongo (8), division (7).

(2) Fight/save: struggle (13), save (8), movement (8), oppose (6).

(3) Other: dear (9), centre (9), happy (9), interior (8), business (7), future (7), respond (6), redeem (6), elected (6).

The main theme in this class is the preservation of the political and territorial unity of Congo, especially after independence. As already stated, Lumumba was favourable to the existence of a single and centralized Congolese state as a prelude to a 
pan-African state. Using typical nationalistic rhetoric (Azzi, 1998; Klein, 2000; Reicher \& Hopkins, 2001a) he justifies this goal by the fact that the Black people in Congo, but also throughout Africa, form a whole, a 'nation', sharing a common destiny and culture that unites them. Yet the forces of ethnic or religious division, as well as foreign interference (especially from Belgium) were at work, bringing about the threat of a 'balkanization' of the country. Lumumba therefore invites the Congolese people to fight these forces. Note that he envisages Congolese unity as a first step in the conquest of African unity (see excerpt 2 below).

Typical excerpts for this class are:

All our countrymen must be persuaded that they will not serve the general interest of the country if they are divided or if they foster such divisions, any more than they would serve it by balkanizing our country and partitioning it into weak little states. Once the territory is balkanized, it will be difficult to achieve national unity again. (Léopoldville, March 1959, p. 7I).

Yesterday Europeans tried to divide us: they tried to divide the Bakongos and the Bangalas ${ }^{7}$, they tried to divide Kasa-Vubu and Lumumba; and we are proving to all these people that today we are united. And we are going to safeguard our national unity, for it is this unity that will make the Congo a great nation in the heart of Africa, and the Congo is going to play a great role in liberating the remainder of Africa tomorrow. (Stanleyville, July 1960, p. 273).

\section{Class 6: Stigmatization of Belgian action (8.38\% of ECUs)}

This class was divided into four subclasses:

(1) Military: military (20), troops (24), situation (17), army (15), general (14), security (6).

(2) Regions and travel: Katanga (21), Léopoldville (13), arrive (11), send (9), inspect (9), (landing) plain (9), Bukavu (7), plane (7), aviation (6).

(3) Authorities: Provincial (Governor) (10), secretary (10), President (9), chief (13), council (11), central (Government) (6), police (6).

(4) Other: day (11), measure (6).

This class mainly contains excerpts describing the relations, both military and political, between the Congolese and the Belgian authorities after independence. Lumumba stigmatizes the occupation of Katanga by the Belgians, motivated by the desire to keep the Union Minière. He also describes how he and his collaborators tried to travel around Congo to inspect the situation and were constantly prevented from doing so by Belgian troops and authorities, or by rival Congolese troops, who supported the secession of Katanga. A typical excerpt of this class is the following:

In its Constitution, Belgium acknowledged the independence of Congo, which is an indivisible and indissoluble political entity. The same Belgium sent troops to Katanga. The same Belgium sent a special emissary to Tshombe ['President' of Katanga], the same Belgium prepared the secession of Katanga, just to have the Union Minière, just to control our country. (Congolese Radio, July I 960).

\section{Links with independent variables}

Using independence tests, ALCESTE computes the relation between a lexical class and levels of an independent variable. If there is a significantly greater proportion of ECUs

\footnotetext{
${ }^{7}$ The Bakongos are a Bantu ethnic group dwelling mainly in the Western part of Congo. The ABAKO party led by Joseph Kasa-Vubu politically represented them. 'Bangalas' is used to refer to the speakers of Bangala who live in the Upper Congo region.
} 
belonging to a class at one level of the independent variable than at ather levels combined, the class is considered as associated with this level. The program performs the same analysis for all other classes and levels of the independent variable. In the present instance, the speeches were classified according to the dominant group membership of the audience: Congolese, Belgians, or mixed. This coding was based on historical sources describing the context in which the speeches were delivered ${ }^{8}$ (De Vos, 1961; Van Lierde, 1963; Willame, 1994). A second independent judge made the same coding and showed a high level of agreement $(\kappa=.87)$. A third judge resolved the disagreements.

The first class ('anti-colonialism') was associated with the Congolese audience, $\chi^{2}(1)=36.85, p<.001$. The second class ('cooperation') with the Belgian audience, $\chi^{2}(1)=19.39, p<.001$, and the third ('unitarianism') and sixth ('stigmatization of Belgian action') classes with the Congolese audience, $\chi^{2}(1)=56.98, p<.001$ and $\chi^{2}(1)=104.38, p<.001$, respectively.

Another independent variable was the period at which the speech was delivered. Based on available chronologies (Gerard-Libois, 1960; Gerard-Libois \& Heinen, 1989); three subperiods were considered as a function of major events leading to the independence of Congo and directly following it. These periods are: (1) 11 December 1958 (first speech as leader of the MNC) to the Round Table in Brussels (starting in January 1960); (2) between 1 February and 29 June 1960; and (3) between 30 June (Independence) and his death in January 1961. This analysis revealed that period 3 was associated with classes 3 (unitarianism) and 6 (stigmatization of the Belgians), $\chi^{2}(1)=63.09, p<.001$, and $\chi^{2}(1)=104.4, p<.001$, respectively. ${ }^{9}$

Contrary to an experimental design, time and audience group membership cannot be treated as mutually independent. For example, Lumumba was more likely to address Belgians than Congolese during the first period ( $72 \%$ of the ECUs during this period were addressed to Belgians) but during the third period, he almost exclusively addressed audiences classified as Congolese ( $94 \%$ of ECUs in this time period). Lack of independence between time and audience could induce confounds; thus, effects of audience could actually be due to time (or vice versa). In order to assess this possibility, we carried out separate hierarchical log-linear analyses (for an introduction to this method, see Klein \& Azzi, 1999) to examine whether the effects of audience yielded by ALCESTE persisted when including period in the model (following the logic of a $2 \times 2$ ANOVA). These models always included audience (either Congolese vs.

\footnotetext{
${ }^{8} \mathrm{~A}$ potential problem in this analysis strategy resides in the coding of the audience's group membership. It is very clear that to make these data amenable to statistical analysis we had to 'objectify' the group membership of the audience and, hence, face the hazards of 'gross categorizations' denounced by discourse analysts (Potter \& Wetherell, 1987). We assumed that, to some extent, any Belgian audience had specific characteristics that were relevant to a common strategy. This may be contested: when Lumumba addressed a mob in Leopoldville or his rival Kasa-Vubu, both instances were considered as involving an African audience. It is very likely that these audiences were construed differently by Lumumba. Similarly, the same audience may be perceived differently depending on the goals of the communicator (Reicher \& Hopkins, 1996a). It is a limit of the present analysis strategy that one cannot precisely study how particular audiences were actually construed. In order to do so, one would have to perform a microscopic analysis of single speeches. Nevertheless, discourse and subjective perception take place within a material reality, with 'pre-constituted objects and social subjects' (Fairclough, 1992, p. 6I). One can hardly deny that being Belgian or Congolese was a crucial categorization in the context of the decolonization process. It is true that other categorizations (e.g. ethnic) may account for some variation in his discourses. Nonetheless, our assumption is that, over and above these other, subjective, constructions of the audiences, this particular categorization was more relevant in the framework of Lumumba's rhetorical strategies during this period. Note also that the Congolese audience included three speeches delivered in friendly African countries, Ghana and Nigeria, but widely communicated in Congo.

${ }^{9}$ The high values of the statistics are due in part to the size of the corpus (and hence a high frequency of ECUs).
} 
others or Belgians vs. others), period $(1,2,3)$ and the dependence between period and audience. We found that the dependence between audience (Congolese vs. others) and class 1 ( 1 vs. others) remained significant even if the dependences between period and class were also included in the model, likelihood ratio (LR) $(1)=30.01, p<.001$ : 69.6\% of ECUs belonging to this class were addressed to Congolese audiences (vs. $57.6 \%$ of those belonging to other classes). In other words, the effect of the period remained significant when audience was controlled for. Using a parallel analysis we found that the dependence between audience (Belgians vs. others) and class 2 also significantly improved the fit of the model, $\operatorname{LR}(1)=79.74, p<.001: 77.5 \%$ of ECUs belonging to this class were addressed to Belgian audiences (in contrast to $51.3 \%$ of those belonging to other classes). So did the dependence between class 3 and the Congolese audience, $\operatorname{LR}(1)=8.6, p<.01(80.7 \%$ of the ECUs belonging to this class vs. $57.1 \%$ of those belonging to other classes were addressed to Congolese audiences). On the other hand, the dependence between class 6 and the Congolese audience was only marginally significant, $\operatorname{LR}(1)=3.42, p=.064(85.7 \%$ vs. $57.3 \%)$.

To examine whether the impact of the period on the use of class 3 persisted when controlling for audience, we used a similar approach to test whether the inclusion of a dependence between period (3 vs. others) and class (3 vs. others) significantly improved the fit of a model including audience (Congolese, mixed, Belgian), period (3 vs. others), class (3 vs. others), and the dependence between class and audience. A parallel analysis was performed on class 6 . In both instances, addition of this term significantly improved the fit of the model, $\operatorname{LR}(1)=6.12, p<.05$ and $\operatorname{LR}(1)=42.71$, $p<.001$. $65.3 \%$ of ECUs belonging to class 3 (vs. $40.6 \%$ of other classes) and $80.4 \%$ of those belonging to class 6 (vs. 39.9\% of other classes) were spoken during period 3 . Overall, these results confirm the analyses performed by ALCESTE and indicate that audience and period have distinct statistical effects on the use of the four lexical classes.

Based on the indications provided by the above analyses, the pattern in need for an interpretation is therefore the following: Lumumba was particularly likely to use an anti-colonialist rhetoric to address his Congolese audiences and to use a cooperative one to address his Belgian audiences; after 30 June 1960, he tended to emphasize the unity of Congo and to blame the Belgians when addressing his Congolese audiences.

\section{Discussion}

While the first lexical class isolated by ALCESTE involved a description of Belgians as oppressors, the second class portrays them as partners supporting the development of the Congo. Excerpts associated with class 6 describe Belgians as contributing to the dissolution of the State by interfering with the prerogatives of the Congolese government. Implicit in these classes are three views of the Congo. The first and sixth classes describe the country as oppressed and a victim of Belgian action. In the second, Congo is depicted as an infant State needing the help of other countries to begin its development. In the third class, Congo is viewed as an entity, a country composed of a single people, whose unity is being threatened. Thus, at least three distinct representations of the groups involved and of their relations are communicated.

These views are not equally likely to be expressed as a function of the audience. Anti-colonialism, which depicts the intergroup context as opposing the 'bad' 
colonialists and the 'good' Congolese, is strongly associated with the Congolese audience. This can be interpreted in strategic terms. Before 1959, most Congolese were not even sensitized to the idea of independence: mobilizing them into supporting this project could therefore be seen as crucial. In line with SCT, creating a negative image of the out-group (the Belgian colonialists) and a victimized in-group identification may be useful for doing so.

Cooperation is associated with the Belgian audiences, whom Lumumba only encountered before Independence. During this period, it was necessary to determine which course an independent Congo should take and how it could be viable. As history showed, disintegration and collapse were plausible prospects if the country was not assisted by other nations. An independent Congo would hardly be viable without support from Belgium or other Western countries, as the Congolese workforce was overwhelmingly uneducated and unskilled (De Vos, 1961; GerardLibois \& Heinen, 1989; Willame, 1994). Furthermore, the bulk of the finances were in the hands of the Belgians. Hence, the possible exodus of skilled Belgian labour and capital could have been harmful to the fulfilment of Lumumba's project. By insisting on the cooperative relationships between the Belgians and the Congolese, and by describing Congo as an infant State needing assistance, Lumumba could mobilize Belgians into supporting his project. He also contested negative stereotypes of Congolese and emphasized their friendly intentions. In doing so, he sought to reassure the Belgians in order to prevent them from fleeing the potential chaos of an independent Congo. Belgians were tempted to leave the country, as their future under Congolese rule seemed less than certain. Exposed to tales of massacres aimed at them, many feared hostile actions on the part of their former subjects, as the latter could be moved to revenge (Stengers, 1989; Willame, 1994). The association of the second class with Belgian audiences is therefore perfectly consistent with the view that group representations can be used to mobilize audiences into supporting the communicator's political agenda.

While present in the first three periods, unitarianism (lexical class 3) is more strongly associated with the final period, i.e. when Lumumba was Prime Minister and had to face several challenges to the unity of the Congo (e.g. the secessions of Kasai and Katanga). At odds with the challenges he faced, Lumumba asserts the unity of his people and the desirability of renewed harmony. Simultaneously, he stigmatized the interference of the Belgian troops and authorities (lexical class 6), who supported the secession of Katanga. The emphasis on the unity of the country can be partially interpreted as resulting from a heightened salience of the Congolese identity; faced with a threat on their social identity, highly identified group members are particularly likely to reassert the homogeneity of the in-group (Doosje \& Ellemers, 1997). They are also more likely to display in-group bias (Branscombe, Ellemers, Spears, \& Doosje, 1999), which may explain the heightened stigmatization of the Belgians. However, the use of these representations is also interpretable in strategic terms: obviously, describing Congo as an 'entity' is mainly necessary when addressing the Congolese audiences Lumumba wants to keep united in order to fulfil his objectives. This pattern is therefore consistent with Klein et al.'s experimental study (2000) showing that unitarists faced with a threat to the existence of their State are particularly likely to describe their group as an entity when addressing an audience perceived as separatist.

In each of these instances, Lumumba is trying to offer a view of intergroup relations opposing that shared by his audience, and his representations cannot be isolated from 
Table I. Representations used by Lumumba in the context of the political projects supported by his audiences

\begin{tabular}{llll}
\hline Anti-colonialism & \multicolumn{1}{c}{ Cooperation } & $\begin{array}{c}\text { Unitarianism/ } \\
\text { Stigmatization of the } \\
\text { Belgians }\end{array}$ \\
\hline Representations used & $\begin{array}{l}\text { Congolese as victim } \\
\text { of Belgian oppression }\end{array}$ & $\begin{array}{l}\text { Congolese as an infant } \\
\text { State having friendly } \\
\text { sentiments towards } \\
\text { Belgium } \\
\text { Belgium expected to } \\
\text { assist their } \\
\text { independent State }\end{array}$ & $\begin{array}{l}\text { The Congo as a } \\
\text { single, entitative, } \\
\text { nation threatened by } \\
\text { hostile Belgian action }\end{array}$ \\
\hline
\end{tabular}

Political project

Unitary and independent Congo

\begin{tabular}{llll} 
Opposing representation & $\begin{array}{l}\text { Congolese as } \\
\text { benefiting from } \\
\text { Belgian action }\end{array}$ & $\begin{array}{l}\text { Congolese as hostile } \\
\text { to Belgians and } \\
\text { incapable of assuming } \\
\text { their Independence }\end{array}$ & $\begin{array}{l}\text { Congolese as a mosaic } \\
\text { of distinct ethnic } \\
\text { groups }\end{array}$ \\
\hline
\end{tabular}

this argumentative context (see Table 1). Whereas the representations used by Lumumba always supported the same political project, the views he rejected through these classes of discourse each support a different political project. At first sight, these representations may seem contradictory: for example, the first class ('anti-colonialism') describes the relations between the Congolese and the Belgians as inherently antagonistic, while the second one ('cooperation') depicts the relations between the two countries as cooperative and cordial. Nevertheless, a general consistency in Lumumba's political goals underlies this surface variability. His discourse consistently aims to mobilize audiences into supporting the project of a unified and independent Congo. As these audiences have different positions and capacities for action in the social context, different forms of collaboration are expected from them and, hence, different representations are used to elicit those actions. Altogether, this analysis supports the discourse analytic perspective (Billig, 1985, 1987; Potter \& Wetherell, 1987; Reicher \& Hopkins, 1996a, 1996b; Wetherell \& Potter, 1992), which emphasizes that the use of categories and group representations needs to be considered in the argumentative context in which they are expressed.

Variations in the representations used by Lumumba can certainly be viewed as a consequence of social change. It is obvious that 'objective' changes in the structure of intergroup relations between the 1950s and the early 1960s explain the transition from the praise of Belgians as liberators of Congo to their stigmatization as ruthless 
oppressors. Historical change between 1959 and the summer of 1960 also partially accounts for a renewed antipathy towards Belgians at the end of this period. Such transitions can be understood in terms of social identity theory (Tajfel \& Turner, 1986) and SCT (Turner et al., 1987); for example, one may argue that as 'cognitive alternatives' to colonialism emerged in the course of the 1950s (e.g. the independence of Congo-Brazzaville, of Ghana, Lumumba's visit to Belgium, etc.), the Belgians' position began to be perceived as illegitimate and unstable and they became a salient, negatively valued, out-group.

Nevertheless, the performative role of the representations used by Lumumba is not fully addressed by these theories. The cognitive salience of a specific identity does not necessarily entail the expression of a single normative representation of the group. Several different representations may be used strategically in the context of the same identity (Klein \& Azzi, 2001; Reicher, Spears, \& Postmes, 1995). While effects of time can be interpreted in terms of cognitive salience, it is difficult to account for audience effects solely in this manner, especially in view of the fact that the effects of the audience factor persist when controlling for the effect of time. For example, during periods 1 and 2, Lumumba stigmatized Belgians in front of Congolese audiences and praised them in front of Belgian audiences. Can we assume that, during the very same period, Lumumba suddenly viewed Belgians more favourably when he addressed them? More plausibly, these effects need to be interpreted in the context of the argumentative strategies he was pursuing as a function of the specific audience he was addressing. In this regard, the present analysis suggests that the concept of political project is crucial if we want to assess variation in the public expression of group representations. While the project associated with an identity in a particular context may remain stable over long periods of time, the representations used to convince audiences to support it can take a variety of forms.

The present analysis suggests that the link between a particular representation and social change depends on the argumentative context in which this representation is used (see also, Billig, 1995; Reicher et al., 1997). SDT (Sidanius \& Pratto, 1999) makes a clear distinction between hierarchy-enhancing myths and hierarchyattenuating myths, thereby suggesting that some representations tend to be uniformly associated with either change or stability. Similarly, SJT (Jost \& Banaji, 1994) and SET (Yzerbyt et al., 1997, 2001) suggest that the personological properties of social stereotypes make them particularly amenable to justifying the existing social order. Although these theories convincingly argue that there is regularity in the extent to which some representations are used for implementing each one of these goals, our analysis suggests that the nature of this link cannot necessarily be ascertained without taking into account the communicational context in which they are used. Thus, the representation of Congo as an infant State needing the help of a friendly Belgium (class 2) is truly hierarchy-attenuating in the present instance (as it serves to reassure the Belgians that they should not fear a disengagement from Congo) but it could as well be hierarchy-enhancing in another context; Belgians could, and did, use this type of representation to justify a pursuit of the colonial endeavour.

It is, of course, difficult to evaluate the extent to which Lumumba's speeches actually induced social change. Most historians of the period acknowledge that Lumumba's rhetorical skills were crucial to the occurrence of such a rapid decolonization (Gerard-Libois \& Heinen, 1989; Stengers, 1989). More generally, the relationship between discourse and social change, that we have presented here as depending on 
mobilization, cannot be reduced solely to this aspect. Discourse constitutes a social practice, the scope of which reaches far beyond mobilization (Fairclough, 1992; Potter \& Wetherell, 1987). Moreover, a discourse which is specifically aimed at inducing mobilization, such as Lumumba's, may not succeed in eliciting efficient collective action but may, instead, create the 'cognitive alternatives' necessary for other types of action to occur (Tajfel \& Turner, 1986). SRT may be best equipped for explaining such dynamics; according to this theory, public speakers do not completely fashion the social representations endorsed by their audiences but they can facilitate the emergence of new social representations, or the transformation of existing ones. These social representations are then viewed as the outcome of a form of negotiation between the speaker and the audience. This analysis suggests that further work geared at understanding the relationship between group representations and actual collective action would benefit from integrating both the social-representational and the discourse-analytic perspectives, in spite of the different metatheoretical assumptions of these two traditions (Potter \& Edwards, 1999). In that perspective, a political discourse should be considered as a discursive act aiming at creating or modifying social representations held by the audience in order to facilitate social mobilization in line with a political project.

At a methodological level, the results of this study demonstrate that combining qualitative and quantitative approaches to discourse is a promising avenue for social psychology. By offering the opportunity to analyse non-reactive and situated discourse practices, this methodological approach offers some of the advantages of discourse analysis. But apparent lack of objectivity, for example in the choice of excerpts, makes these approaches vulnerable to criticism. The present approach offers a tentative response to such scepticism by relying on multivariate and inferential statistics. In addition, its macroscopic scope makes it particularly suited to the analysis of longitudinal and historical data, a path which social psychologists have too rarely explored. In conclusion, the present study suggests that the role of group representations in social change cannot be ascertained if these representations are only viewed as cognitive consequences of social change. They also need to be studied in the context of the political projects they seek to justify. Group representations can be used to mobilize both in-group and out-group members into supporting these projects. Ignoring this political function of group representations would obliterate the inherently dynamic role they play in the evolution of social systems.

\section{Acknowledgments}

We wish to thank Vanessa Hambursin for her assistance in the coding of the speeches. We also express our gratitude to Manuela Barreto, Rodrigo Brito, Moira Dean, Margarita Sanchez-Mazas, Stefan Stürmer, Ian Williamson and to Margaret Wetherell and three anonymous referees for their comments on an earlier version of this text.

\section{References}

Alexander, M. G., Brewer, M. B., \& Herrmann, R. K. (1999). Images and affect: A functional analysis of outgroup stereotypes. Journal of Personality and Social Psychology, 77, 78-93. 
Augoustinos, M. (2001). Social categorization: towards theoretical integration. In K. Deaux \& G. Philogene (Eds), Representations of the social: Bridging theoretical traditions (pp. 201-216). Oxford: Blackwell.

Azzi, A. E. (1998). From competitive interests, perceived injustice, and identity needs to collective action: psychological mechanisms in ethnic nationalism. In C. Dandeker (Ed.), Nationalism and Violence (pp. 73-138). New Brunswick, NJ: Transaction.

Bar-Tal, D. (1990). Group Beliefs. New York: Springer.

Bar-Tal, D. (1997). Formation and change of ethnic and national stereotypes: An integrative model. International Journal of Intercultural Relations, 21, 491-523.

Bar-Tal, D., \& Labin, D. (2001). The effect of a major event on stereotyping: Terrorist attacks in Israel and Israeli adolescents' perceptions of Palestinians, Jordanians and Arabs. European Journal of Social Psychology, 31, 265-280.

Beardsworth, A. (1980). Analysing press content: Some technical and methodological issues. Sociological Review Monographs, 29, 371-395.

Billig, M. (1985). Prejudice, categorization and particularization: From a perceptual to a rhetorical approach. European Journal of Social Psychology, 15, 79-103.

Billig, M. (1987). Arguing and thinking: A rhetorical approach to social psychology. Cambridge: Cambridge University Press.

Billig, M. (1995). Banal nationalism. London: Sage.

Boudes, N., \& Cellier, J.-M. (1998). Etude du champ d'anticipation dans le contrôle du trafic aérien [Study of the anticipation field in air traffic control], Le Travail Humain, 61, 29-50.

Braeckman, C. (2002). Lumumba, un crime d'Etat [Lumumba, a State crime]. Brussels, Belgium: Aden.

Branscombe, N. R., Ellemers, N., Spears, R., \& Doosje, B. (1999). The context and content of social identity threat. In N. Ellemers, R. Spears, \& B. Doosje (Eds.), Social Identity: Context, commitment, content (pp. 35-59). Oxford: Blackwell.

Breakwell, G. M. (1993). Integrating paradigms: Methodological implications. In G. M. Breakwell \& D. V. Canter (Eds.), Empirical approaches to social representations (pp. 180-201). Oxford: Oxford University Press.

Breakwell, G. M. (2001). Social representational constraints upon identity processes. In K. Deaux \& G. Philogene (Eds.), Representations of the social: Bridging theoretical traditions (pp. 271-284). Oxford: Blackwell.

Chryssochoou, X., \& Volpato, C. (2002). The genesis of collective action: An analysis of the rbetorical strategies in the communist manifesto. Unpublished manuscript: University of Surrey.

De Vos, P. (1961). Vie et mort de Patrice Lumumba [Life and death of Patrice Lumumba]. Paris: Calmann-Levy.

De Witte, L. (1999). L'assasinat de Lumumba [Lumumba's assassination]. Paris: Karthala.

Doosje, B., \& Ellemers, N. (1997). Stereotyping under threat: The role of group identification. In R. Spears, P. J. Oakes, N. Ellemers \& S. A. Haslam (Eds.), The social psychology of stereotyping and group life (pp. 257-273). Oxford: Blackwell.

Durkheim, E. (1898). Représentations individuelles et représentations collectives. [Individual and collective representations]. Revue de Métaphysique et de Morale, VI, 273-302.

Edwards, D., \& Potter, J. (1992). Discursive psychology. Thousand Oaks, CA, US: Sage Publications Inc.

Fairclough, N. (1992). Discourse and social change. Oxford: Polity Press.

Farr, R. M., \& Moscovici, S. (1984). Social representations. Cambridge: Cambridge University Press.

Fiske, S. T. (1998). Stereotyping, prejudice, and discrimination. In D. T. Gilbert, S. T. Fiske \& G. Lindcey (Eds.), The handbook of social psychology, Vol. 2 (4th ed.), pp. 357-411). Boston, MA: McGraw-Hill.

Gerard-Libois, J. (1960). Congo 1960. Brussels, Belgium: CRISP. 
Gerard-Libois, J., \& Heinen, J. (1989). Belgique Congo 1960. Brussels, Belgium: Pol-His.

Habermas, J. (1987). The theory of communicative action. Lifeworld and system: A critique of functionalist reason, Vol. II. Cambridge: Polity Press.

Haslam, S. A., \& Turner, J. C. (1992). Context-dependent variation in social stereotyping. 2. The relationship between frame of reference, self-categorization and accentuation. European Journal of Social Psychology, 22, 251-277.

Haslam, S. A., Turner, J. C., Oakes, P. J., McGarty, C., \& Reynolds, K. J. (1998). The group as a basis for emergent stereotype consensus. In W. Stroebe \& M. Hewstone (Eds.), European review of social psychology (Vol. 8, pp. 203-239). Chichester: Wiley

Hochschild, A. (1998). King Leopold's ghost: A story of greed, terror, and heroism in colonial Africa. Boston, MA: Houghton-Mifflin.

Hodgkin, T. (1956). Nationalism in colonial Africa. London: Muller.

Hopkins, N., \& Moore, C. (2001). Categorizing the neighbors: Identity, distance, and stereotyping. Social Psychology Quarterly, 64, 239-252.

Hopkins, N., \& Rae, C. (2001). Intergroup differentiation: Stereotyping as a function of status hierarchy. Journal of Social Psychology, 141, 323-333.

Hopkins, N., Regan, M., \& Abell, J. (1997). On the context dependence of national stereotypes: Some Scottish data. British Journal of Social Psychology, 36, 553-563.

Jost, J. T. (1995). Negative illusions: Conceptual clarification and psychological evidence concerning false consciousness. Political Psychology, 16, 397-424.

Jost, J. T., \& Banaji, M. R. (1994). The role of stereotyping in system-justification and the production of false consciousness. British Journal of Social Psychology, 33, 1-27.

Jost, J. T., Burgess, D. T., \& Mosso, C. O. (2001). Conflicts of legitimation among self, group, and system: The integrative potential of system justification theory. In J. T. Jost \& B. Major (Eds.), The psychology of legitimacy (pp. 363-390). Cambridge: Cambridge University Press.

Jovchelovitch, S. (2001). Social representations, public life, and social construction, In K. Deaux \& G. Philogene (Eds.), Representations of the social: Bridging theoretical traditions (pp. 165-182). Oxford: Blackwell.

Klein, O. (2000). Contribution à une approche pragmatique de l'expression des stéréotypes [Contribution to a pragmatic approach on the expression of stereotypes]. Unpublished doctoral dissertation. Brussels, Belgium: Université Libre de Bruxelles.

Klein, O., \& Azzi, A. E. (1999). L'analyse log-linéaire en psychologie sociale: Une introduction [Log-linear analysis in social psychology: An introduction]. Cabiers Internationaux de Psychologie Sociale, 42, 102-124.

Klein, O., \& Azzi, A. E. (2001). The strategic confirmation of meta-stereotypes: How group members attempt to tailor an out-group's representation of themselves. British Journal of Social Psychology, 41, 279-293.

Klein, K., Azzi, A. E., Brito, R., \& Berckmans, S. (2000). Nationalism and the strategic expression of identity. In T. Postmes, R. Spears, M. Lea, \& S. D. Reicher (Eds.), SIDE issues centre stage: Recent developments in studies of de-individuation in groups (pp. 131-141). Amsterdam: Royal Netherlands Academy of Arts and Sciences.

Kronberger, N., \& Wagner, W. (2000). Keywords in context: Statistical analysis of text features. In M. B. Bauer \& G. Gaskell (Eds.), Qualitative researching with text, image and sound: $A$ practical handbook (pp. 299-317). Thousand Oaks, CA: Sage.

Licata, L. (2001). Identités représentées et représentations identitaires: L'effet des contextes comparatif et sociopolitique sur la signification psychologique des identités géopolitiques [Represented identities and 'identitary' representations: The effect of comparative and sociopolitical contexts on the psychological meaning of geopolitical identities]. Unpublished doctoral dissertation. Brussels, Belgium: Université Libre de Bruxelles.

Licata, L., \& Klein, O. (2000). Situation de crise, explications profanes et citoyenneté: L'affaire Dutroux. [Situation of crises, lag explanations and citizenship: The Dutroux affair]. Cabiers Internationaux de Psychologie Sociale, 47-48, 155-174. 
Lumumba, P. (1962). Congo, my country. London: Pall Mall Press.

Mannheim, K. (1929/1972). Ideology and utopia. London: Routledge and Kegan Paul.

Marchal, J. (1999). L'Histoire du Congo 1910-1945 (Vol.1): Travail forcé pour le cuivre et l'or [History of Congo 1910-1945: Forced labour for copper and gold]. Borgloon, Belgium: Paula Bellings.

Marchal, J. (2000). L'Histoire du Congo 1910-1945 (Vol. 2): Travail forcé pour le rail [History of Congo 1910-1945: Forced labour in railway construction]. Borgloon, Belgium: Paula Bellings.

Marchal, J. (1999). L'Histoire du Congo 1910-1945 (Vol 3): Travail forcé pour l'buile de palme de Lord Leverhulme [History of Congo 1910-1945: Forced labour for Lord Leverhulme's palm oil]. Borgloon, Belgium: Paula Bellings.

Markovà, I. (1996). Towards an epistemology of social representations. Journal for the Theory of Social Behaviour, 26, 177-196.

Martelli, G. (1962). Leopold to Lumumba: A history of the Belgian Congo 1877-1960. London: Chapman and Hall.

Moscovici, S. (1961). La psychanalyse, son image et son public. Paris: Presses Universitaires de France.

Moscovici, S. (1976). Social influence and social change. London: Academic Press.

Mugny, G. (1982). The power of minorities. London: Academic Press.

Mugny, G., Quiamzade, A., \& Tafani, E. (2001). Dynamique représentationnelle et influence sociale [Representational dynamics and social influence]. In P. Moliner (Ed.), La dynamique des représentations sociales [The dynamics of social representations] (pp. 123-162). Grenoble, France: PUG.

Ngoma-Binda, P. (1997). La pensée politique de Lumumba: L'autre face du discours révolutionnaire [Lumumba's political thought: The other side of revolutionary discourse]. In P. Halen \& J. Riesz (Eds.), Patrice Lumumba entre Dieu et Diable: Un béros africain dans ses images (pp. 335-349). Paris: L'Harmattan.

Nyunda, Y. R. (1997). Patrice Lumumba en son temps: Un modéré? [Patrice Lumumba in his time: A moderate?]. In P. Halen \& J. Riesz (Eds.), Patrice Lumumba entre Dieu et Diable: Un héros africain dans ses images (pp. 295-309). Paris: L'Harmattan.

Oakes, P. J., Haslam, S. A., \& Turner, J. C. (1994). Stereotypes and social reality. Oxford: Blackwell.

Potter, J., \& Edwards, D. (1999). Social representations and discursive psychology: From cognition to action. Culture and Psychology, 5(4), 447-458.

Potter, J., \& Wetherell, M. (1987). Discourse and social psychology: Beyond attitudes and behavior. London: Sage.

Pratto, F., Sidanius, J., Stallworth, L., \& Malle, B. L. (1994). Social dominance orientation: A personality variable predicting social and political attitudes. Journal of Personality and Social Psychology, 67, 741-763.

Reicher, S. D. (1984). The St. Pauls' riot: An explanation of the limits of crowd action in terms of a social identity model. European Journal of Social Psychology, 14, 1-21.

Reicher, S. D. (1996a). 'The Battle of Westminster': Developing the social identity model of crowd behaviour in order to explain the initiation and development of collective conflict. European Journal of Social Psychology, 26, 115-134.

Reicher, S. D. (1996b). Social identity and social change: Rethinking the context of social psychology. In W. P. Robinson (Ed.), Social groups and indentities: Developing the legacy of Henry Tajfel (pp. 317-336). Oxford: Butterworth-Heinemann.

Reicher, S. D., \& Hopkins, N. (1996a). Self-category constructions in political rhetoric: An analysis of Thatcher's and Kinnock's speeches concerning the British miners' strike (1984-5). European Journal of Social Psychology, 26, 353-371.

Reicher, S. D., \& Hopkins, N. (1996b). Seeking influence through characterizing selfcategories: An analysis of anti-abortionist rhetoric. British Journal of Social Psychology, 35, 297-311. 
Reicher, S. D., \& Hopkins, N. (2001a). Self and nation. London: Sage.

Reicher, S. D., \& Hopkins, N. (2001b). Psychology and the end of history: A critique and a proposal for the psychology of social categorization. Political Psychology, 22, 383408.

Reicher, S. D., Hopkins, N., \& Condor, S. (1997). Stereotype construction as a strategy of influence. In R. Spears, P. Oakes, N. Ellemers, \& S. A. Haslam (Eds.), The social psychology of stereotyping and group life (pp. 94-118). Oxford: Blackwell.

Reicher, S. D., Spears, R., \& Postmes, T. (1995). A social identity model of deindividuation phenomena. European Review of Social Psychology, 6, 161-198.

Reinert, M. (1993). Les 'mondes lexicaux' et leur 'logique' à travers l'analyse statistique d'un corpus de récits de cauchemars ['lexical worlds' and their 'logic' through the statistical analysis of a corpus of nightmares narratives]. Langage et Société, 5-39.

Reinert, M. (1996). ALCESTE (Version 3.0). Toulouse, France: Images.

Ricoeur, P. (1986). Lectures on ideology and utopia. New York: Columbia University Press.

Rutland, A., \& Cinnirella, M. (2000). Context effects on Scottish national and European self-categorization: The importance of category accessibility, fragility and relations. British Journal of Social Psychology, 39, 495-519.

Sidanius, J., \& Pratto, F. (1999). Social dominance: An intergroup theory of social hierarchy and oppression. New York: Cambridge University Press.

Staerklé, C. (2003). The free and the poor: Value-based and structural justification of global inequality with perceived individualism. Manuscript submitted for publication.

Stengers, J. (1989). Congo: Mythes et réalités. 100 ans d'histoire [Congo: Myths and reality. 100 years of history]. Paris- Louvain-La-Neuve: Duculot.

Tajfel, H. (1981). Human groups and social categories. Cambridge: Cambridge University Press.

Tajfel, H., \& Turner, J. C. (1986). The social identity theory of intergroup behavior. In S. Worchel \& G. Austin (Eds.), The psychology of intergroup relations (pp. 7-24). Chicago: Nelson-Hall.

Taylor, D. M., \& McKirnan, D. J. (1984). A five-stage model of intergroup relations. British Journal of Social Psychology, 23, 291-300.

Turner, J. C., Hogg, M. A., Oakes, P. J., Reicher, S. D., \& Wetherell, M. S. (1987). Rediscovering the social group: A self-categorization theory. Oxford: Blackwell.

Vala, J. A. (1998). Représentations sociales et perceptions intergroupales [Social representations and intergroup perceptions]. In J. L. Beauvois, R. V. Joule, \& J. M. Monteil (Eds.), Perspectives cognitives et conduites sociales (Vol. 6). Lausanne, Switzerland: Delachaux and Niestlé.

Van Lierde, J. (1963). La pensée politique de Patrice Lumumba [Patrice Lumumba's political thought]. Brussels, Belgium: Des Amis de Présence Africaine. Translated as Van Lierde J. (1972). Lumumba speaks. Boston, MA: Little Brown.

Wagner, W. (1995). Social representations, group affiliation and projection: Knowing the limits of validity. European Journal of Social Psychology, 25, 125-139.

Wetherell, M., \& Potter, J. (1992). Mapping the language of racism: Discourse and the legitimation of exploitation. London: Harvester Wheatsheaf.

Willame, J. C. (1994). Patrice Lumumba: La crise congolaise revisitée [Patrice Lumumba: The Congolese crisis revisited]. Paris: Karthala.

Wrong, M. (2000). In the footsteps of Mr. Kurtz. London: Harper Collins.

Yzerbyt, V. Y., Corneille, O., \& Estrada, C. (2001). The interplay of naive theories and entitativity from the outsider and the insider perspectives. Personality and Social Psychology Review, 5, 141-155.

Yzerbyt, V. Y., \& Rogier, A. (2001). Blame it on the group: Entitativity, subjective essentialism, and social attribution. In J. T. Jost \& B. Major (Eds.), The psychology of legitimacy (pp. 103-134). Cambridge: Cambridge University Press. 
Yzerbyt, V. Y., Schadron, R., \& Rocher, S. (1997). Stereotypes as explanations: A subjective essentialistic view of group perception. In R. Spears, P. Oakes, N. Ellemers, \& S. A. Haslam (Eds.), The social psychology of stereotyping and group life (pp. 20-50). Oxford: Blackwell.

Received I8 December 200I; revised version received I 7 September 2002 